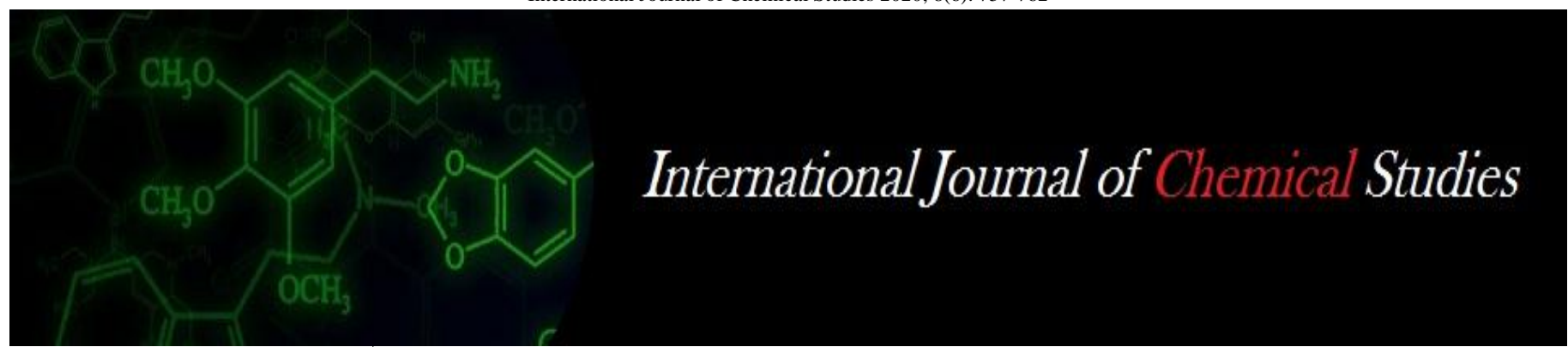

P-ISSN: 2349-8528

E-ISSN: 2321-4902

www.chemijournal.com

IJCS 2020; 8(6): 757-762

(C) 2020 IJCS

Received: 06-09-2020

Accepted: 17-10-2020

Sagar S Patil

PG Student, Soil Science and

Agricultural Chemistry Section,

College of Agriculture, Nagpur,

Maharashtra, India

SS Balpande

Associate Professor, Soil Science and Agricultural Chemistry

Section, College of Agriculture,

Nagpur, Maharashtra, India

\section{NR Mairan}

Senior Research Assistant, Agronomy Section, College of Agriculture, Nagpur,

Maharashtra, India

\section{Mohammad Sajid}

Assistant Professor of Soil

Science and Agricultural

Chemistry Section, College of

Agriculture, Nagpur,

Maharashtra, India

\section{RM Ghodpage}

Associate Professor of Soil

Science and Agricultural

Chemistry Section, College of

Agriculture, Nagpur,

Maharashtra, India
Corresponding Author:

Sagar S Patil

PG Student, Soil Science and Agricultural Chemistry Section, College of Agriculture, Nagpur, Maharashtra, India

\section{Influence of integrated nutrient management using nano phosphatic fertilizer on nutrient use efficiency and yield of wheat (Triticum aestivum L.) in Vertisols}

\author{
Sagar S Patil, SS Balpande, NR Mairan, Mohammad Sajid and RM \\ Ghodpage
}

DOI: https://doi.org/10.22271/chemi.2020.v8.i6k.10860

\begin{abstract}
The experiment was conducted during rabi 2019 to know the effect of integrated nutrient management using nano phosphatic fertilizer on yield, uptake by wheat, soil fertility status and nutrient use efficiency after harvest of wheat. The field trial study showed that, the highest grain yield $\left(3546 \mathrm{~kg} \mathrm{ha}^{-1}\right)$ was obtained by application of Green manuring of sun hemp $+50 \%$ RD of NP through inorganic fertilizers + spraying of $0.5 \%$ of $1000 \mathrm{ppm}$ nano $\mathrm{P}$ suspension at tillering and flowering stage of Wheat, which is an increase by $6 \%$ over Green manuring of sun hemp $+100 \%$ RDF. Phosphorus use efficiency is recorded in between 13.43 to $35.83 \%$ under the application of RDF alone or in combination of nano P suspension.
\end{abstract}

Keywords: Nano phosphatic fertilizer, wheat, tillering, flowering, ghanjivamrut, jivamrut, vermicompost

\section{Introduction}

Wheat (Triticum aestivum L.) is one of the oldest and most important cereal crops in India. Wheat plays an important role in total cereal production and global food security. India is the second largest producer of wheat in the world next to China. Wheat is the second most important crop in India after rice and contributes nearly $35 \%$ to the national food basket. India will require 109 million tons of wheat to feed the population of 1.25 billion by 2020, which can be achieved by growth rate of $2.2 \%$ but the current growth rate is only $1.0 \%$. Wheat cultivation in India occupies 30.42 million-hectare area with the production of 99.87 million tons and productivity of $32.83 \mathrm{q} \mathrm{ha}^{-1}$. Wheat production of India is 99.87 million tons during 2017-18 which is higher by 1.26 million tons than the production of 98.61 million tons achieved during 2016-17 [1]. The average wheat productivity of India is $3283 \mathrm{~kg} \mathrm{ha}^{-1}$. Productivity of wheat can only be enhanced by application of scientific tools and techniques in agriculture. Modern science basically deals with three areas i.e. information technology, biotechnology and nanotechnology.

The crop production and global food security are greatly dependent on fertilizer input constituting nitrogen, Phosphorus and potassium, as it supplements soil nutrients, promotes plant growth and increase crop productivity. Response of P fertilizer in Vertisols of India has been reported to be unpredictable and this has been ascribed to high $\mathrm{P}$ fixation due to high clay content and high content of smectite. Soil of Vidarbha region of Maharashtra are dominated in smectite and varied from 40 to $78 \%$. At present $5 \%$ of the Indian soils have adequate available $\mathrm{P}, 49.3 \%$ under low category, $48.8 \%$ under medium and only $1.9 \%$ under high category ${ }^{[9]}$. The primary goal of integrated nutrient management (INM) is to combine old and new methods of nutrient management into ecologically sound and economically viable farming systems that utilize available organic and inorganic sources of nutrients in a judicial and efficient way ${ }^{[5]}$. Chemical fertilizers like urea, diammonium phosphate (DAP) and single superphosphate (SSP) are used in agriculture to meet the shortage of N, P and K in the soil. But most part of these fertilizers are lost as run-off or volatilized. It is estimated that about 40$70 \%$ of nitrogen, $80-90 \%$ of phosphorus, and 50 to $70 \%$ of potassium of the applied fertilizers is lost to the environment and can't be absorbed by plant applied causing exchequer loss to the nation and environmental pollution as well ${ }^{[12]}$. 
Nano fertilizers are synthesized or modified form of traditional fertilizers, fertilizers bulk materials or extracted from different vegetative or reproductive parts of the plant by different physical, chemical or biological methods with the help of nanotechnology used to improve soil fertility, productivity and quality of agriculture produce ${ }^{[10]}$. Particle size of P-fertilizers greatly influences their agronomic effectiveness. Decreased particle size increases the specific surface area of a fertilizer, which increase the dissolution rate of fertilizers with low solubility in water ${ }^{[8]}$. Nanoparticles are expected to be the ideal candidates for use as a P-fertilizer for plants. Nano-fertilizers are highly effective for precise nutrient management in precision agriculture with matching the crop growth stage for nutrient and may provide nutrient throughout the crop growth period. To increase phosphorus use efficiency and minimize the losses of phosphatic fertilizers, nano phosphatic fertilizer is the best alternative to increase phosphorus use efficiency as well as nutrient uptake and yield of various crops. Nano fertilizer increases fertilizer use efficiency by targeted release of nutrient in adequate proportion without any harmful effect on soil as well as plant [13].

\section{Materials and Methods}

The Hydroxyapatite (HA) source of Phosphorus is used for synthesis of nano phosphatic fertilizer which is prepared by using Chemical precipitation method as demonstrated by Mateus et al., $2007^{[7]}$ in the laboratory of Department of Nanotechnology and Centre for Advanced Research in Plant Tissue Culture, Anand Agricultural University, Anand (Gujarat). A field experiment was conducted during rabi 2019 at Botany Research Farm, College of Agriculture, Nagpur $(\mathrm{MH})$. After the preparation of hydroxyapatite nanoparticles different characterization techniques were used to investigate their particle size (nm), poly dispersive index (PDI) and count rate (Kcps), zeta potential and morphological characteristics at same place where nano $\mathrm{P}$ is synthesized. Dynamic light scattering measurements for particle size (nm) and Polydispersity Index showed that the particle size was in the range of $145-172 \mathrm{~nm}$ with Polydispersity Index of 0.274 to 0.328 , it is the mid-range value and indicating that the particles were in disperse form in aqueous suspension. From the analysis, the zeta potential value was found to be $(-47.13$ and $-47.23 \mathrm{mV}$ ) respectively for two sprayings, revealing the better stability of synthesized HAP nanoparticles in aqueous suspension ${ }^{[16]}$.

The soil used for the experiment was alkaline in reaction with low in available nitrogen, medium in available phosphorus and high in available potassium. With respect to DTPAmicronutrients, $\mathrm{Zn}, \mathrm{Mn}$ and $\mathrm{Fe}$ was in medium and $\mathrm{Cu}$ present in sufficient range. The experiment is laid down in randomized block design which had nine treatments and three replications. The treatments were $\mathrm{T} 1$ [Absolute control], T2 $\left[\mathrm{GM}^{*}+100 \% \mathrm{RDF}\right], \mathrm{T} 3\left[\mathrm{GM}^{*}+\right.$ Ghanajivamrut $5 \mathrm{t} \mathrm{ha}^{-1}+$ Azophos seed treatment $+50 \%$ RD of NP through fertilizer + Jivamru], T4 $\left[\mathrm{GM}^{*}+\right.$ Vermicompost $5 \mathrm{t} \mathrm{ha}^{-1}+$ Azophos seed treatment $+50 \%$ RD of NP through fertilizer + Jivamrut], T5 $\left[\mathrm{GM}^{*}+50 \%\right.$ RD of NP through fertilizer + Foliar spray of $0.5 \%$ of $1000 \mathrm{ppm}$ nano $\mathrm{P}$ suspension at tillering and flowering stage of wheat], T6 [ T3 + Foliar spray of $0.5 \%$ of $1000 \mathrm{ppm}$ nano $\mathrm{P}$ suspension at tillering and flowering stage of wheat], T7 [T4 + Foliar spray of $0.5 \%$ of 1000 ppm nano P suspension at tillering and flowering stage of wheat], T8 $\left[\mathrm{GM}^{*}+\right.$ Ghanajivamrut $\left.5 \mathrm{t} \mathrm{ha} \mathrm{h}^{-1}\right]$ and $\mathrm{T} 9\left[\mathrm{GM}^{*}+\right.$ Vermicompost $5 \mathrm{t} \mathrm{ha}^{-1}+$ Azophos seed treatment + Jivamrut] in which $\mathrm{GM}^{*}$ means green manuring of Sunhemp (Crotolaria juncea). Sunhemp were harvested after 30 days of sowing and incorporated into field by tractor-drawn rotavetor on $3^{\text {rd }}$ November. Wheat $(\mathrm{AKW}-1071)$ was sown on $15^{\text {th }}$ November using $100 \mathrm{~kg}$ seed ha ${ }^{-1}$. Fertilizers used were urea, DAP, muriate of potash and 1000 ppm nano $\mathrm{P}$ fertilizer. Wheat crop was harvested at physiological maturity and yields (Grain and Straw) were recorded.

Grain and straw samples were analysed for nitrogen content by Kjeldahl method (Piper, 1966). Phosphorus and potassium in di-acid $\left(\mathrm{HNO}_{3}: \mathrm{HClO}_{4}\right)$ digest were determined by vanadomolybdate yellow colour method and flame photometer. The soil $\mathrm{pH}$ was determined in 1:2.5 soil water ratio in suspensions using digital $\mathrm{pH}$ meter ${ }^{[4]}$. Electrical conductivity was determined by in 1:2.5 soil water ratio using Conductivity meter ${ }^{[4]}$.Organic carbon from soil was determined by Wet oxidation method ${ }^{[15]}$. The available nitrogen was estimated by alkaline permanganate method described by Subbiah and Asija (1956) [14]. Available Phosphorus was determined by Olsen's method using $0.5 \mathrm{M}$ sodium bicarbonate $(\mathrm{pH} 8.5)$ as extractant and Darco G-60 free from soluble Phosphorus to absorb the dispersed organic matter and make the filtrate colourless for further spectrophotometric analysis. Available potassium was determined by flame photometer using neutral normal ammonium acetate extractant ${ }^{[4]}$. The available sulphur estimated turbidimetrically $\left(\mathrm{CaCl}_{2}\right)$ extract using spectrophotometer described by Chesnin and Yien (1951) ${ }^{[2]}$. DTPA extractable $\mathrm{Zn}, \mathrm{Fe}, \mathrm{Cu}$ and $\mathrm{Mn}$ was estimated by the method described by Lindsay and Norvell (1978) ${ }^{[6]}$ for this $\log$ soil was shaken in $20 \mathrm{~mL} 0.005$ M DTPA buffer solution (Diethylene triamine penta acetic acid containing $0.1 \mathrm{M}$ calcium chloride adjusted to $\mathrm{pH} 7.3$ with $\mathrm{HCl}$ ) for two hours and then filtered and filtrate was subjected to measurement on Atomic Absorption Spectrophotometer (AAS). The nutrient use efficiency $(\%)$ is estimated by following formula:

$$
\operatorname{NUE}(\%)=\frac{\begin{array}{c}
\text { Nutrient uptake in fertilized } \\
\text { plot }\left(\mathrm{kg} \mathrm{ha}^{-1}\right)
\end{array}}{\text { Nutrient Applied }\left(\mathrm{kg} \mathrm{ha}^{-1}\right)} \times 100
$$

\section{Results and discussion}

Effect of INM with nano phosphatic fertilizer on yield attributes and yield of wheat

The data pertaining to effect of INM with nano phosphatic fertilizer on yield attributes and yield of wheat is given in table 1 . 
Table 1: Effect of INM with nano phosphatic fertilizer on yield attributes and yield of wheat

\begin{tabular}{|c|c|c|c|c|}
\hline Treat. No. & Treatment Details & Test weight $(\mathrm{g})$ & Grain yield $\left(\mathrm{kg} \mathrm{ha}^{-1}\right)$ & Straw yield $\left(\mathrm{kg} \mathrm{ha}^{-1}\right)$ \\
\hline $\mathrm{T}_{1}$ & Absolute control & 38.43 & 1657.40 & 2006.00 \\
\hline $\mathrm{T}_{2}$ & $\mathrm{GM}^{*}+100 \% \mathrm{RDF}$ & 42.32 & 3340.21 & 4175.10 \\
\hline $\mathrm{T}_{3}$ & $\begin{array}{c}\mathrm{GM}^{*}+\text { Ghanajivamrut } 5 \mathrm{t} \mathrm{ha}^{-1}+\text { Azophos seed treatment }+50 \% \text { RD of } \\
\text { NP through fertilizer + Jivamrut }\end{array}$ & 39.53 & 3218.00 & 4019.00 \\
\hline $\mathrm{T}_{4}$ & $\begin{array}{c}\mathrm{GM}^{*}+\text { Vermicompost } 5 \mathrm{t} \mathrm{ha}^{-1}+\text { Azophos seed treatment }+50 \% \mathrm{RD} \text { of NP } \\
\text { through fertilizer }+ \text { Jivamrut }\end{array}$ & 41.12 & 3230.00 & 4076.35 \\
\hline $\mathrm{T}_{5}$ & $\begin{array}{c}\mathrm{GM}^{*}+50 \% \text { RD of NP through fertilizer + Foliar spray of } 0.5 \% \text { of } 1000 \\
\text { ppm nano P suspension at tillering and flowering stage of wheat }\end{array}$ & 42.62 & 3546.00 & 4481.43 \\
\hline $\mathrm{T}_{6}$ & $\begin{array}{c}\mathrm{T}_{3}+\text { Foliar spray of } 0.5 \% \text { of } 1000 \text { ppm nano P suspension at tillering and } \\
\text { flowering stage of wheat }\end{array}$ & 42.20 & 3542.00 & 4454.00 \\
\hline $\mathrm{T}_{7}$ & $\begin{array}{c}\mathrm{T}_{4}+\text { Foliar spray of } 0.5 \% \text { of } 1000 \mathrm{ppm} \text { nano P suspension at tillering and } \\
\text { flowering stage of wheat }\end{array}$ & 42.06 & 3217.00 & 4096.55 \\
\hline$T_{8}$ & $\mathrm{GM}^{*}+$ Ghanajivamrut $5 \mathrm{t} \mathrm{ha}^{-1}$ & 39.76 & 1902.37 & 2415.33 \\
\hline $\mathrm{T}_{9}$ & $\mathrm{GM}^{*}+$ Vermicompost $5 \mathrm{t} \mathrm{h}^{-1}+$ Azophos seed treatment + Jivamrut & 39.15 & 1966.00 & 2443.49 \\
\hline \multicolumn{2}{|r|}{$\mathrm{SEm} \pm$} & 2.65 & 126.23 & 170.57 \\
\hline \multicolumn{2}{|r|}{$\mathrm{CD}$ at $5 \%$} & NS & 378.45 & 511.38 \\
\hline
\end{tabular}

The data on test weight of wheat grain as influenced due to different treatments are presented in result revealed that, treatment $\mathrm{GM}^{*}+50 \% \mathrm{RD}$ of NP through fertilizer + Foliar spray of $0.5 \%$ of $1000 \mathrm{ppm}$ nano $\mathrm{P}$ suspension at tillering and flowering stage recorded significantly higher test weight $(42.62 \mathrm{~g})$ of wheat followed by $\mathrm{T}_{2}(42.32 \mathrm{~g}) \mathrm{T}_{6}(42.20 \mathrm{~g})$ and $\mathrm{T}_{7}(42.06 \mathrm{~g})$. However, the treatment effects were not significant.

Among different treatments, $\mathrm{T}_{5}\left(\mathrm{GM}^{*}+50 \% \mathrm{RD}\right.$ of $\mathrm{NP}$ through fertilizer + Foliar spray of $0.5 \%$ of $1000 \mathrm{ppm}$ nano $\mathrm{P}$ suspension at tillering and flowering stage of wheat) resulted in highest grain yield $\left(3545.76 \mathrm{~kg} \mathrm{ha}^{-1}\right)$ and straw yield
(4481.43 kg ha $\left.{ }^{-1}\right) . \mathrm{T}_{5}$ treatment is followed by treatment $\mathrm{T}_{6}$ which comprises of $\mathrm{T}_{3}+$ Foliar spray of $0.5 \%$ of $1000 \mathrm{ppm}$ nano $\mathrm{P}$ suspension at tillering and flowering stage of wheat under which grain yield (3541.97 $\left.\mathrm{kg} \mathrm{ha}^{-1}\right)$ and straw yield recorded $\left(4453.65 \mathrm{~kg} \mathrm{ha}^{-1}\right)$. Similar results were reported by Dhansil et al. (2018) ${ }^{[3]}$, yield of wheat increased by $6 \%$ with application of $\mathrm{GM}^{*}+50 \% \mathrm{RD}$ of NP through fertilizer + Foliar spray of $0.5 \%$ of $1000 \mathrm{ppm}$ nano $\mathrm{P}$ suspension at tillering and flowering stage of wheat, over $\mathrm{GM}^{*}+100 \%$ RDF.

\section{Nutrient uptake by Wheat}

Table 2: Influence of INM with nano phosphatic fertilizer on nutrient uptake by Wheat

\begin{tabular}{|c|c|c|c|c|c|c|c|}
\hline \multirow[t]{2}{*}{ Treat. No. } & \multirow[t]{2}{*}{ Treatment Details } & \multicolumn{2}{|c|}{\begin{tabular}{|c|c|} 
N uptake \\
$\left(\right.$ kg ha $\left.^{-1}\right)$
\end{tabular}} & \multicolumn{2}{|c|}{\begin{tabular}{|c|} 
P uptake \\
$\left(\mathrm{kg} \mathrm{ha}^{-1}\right)$
\end{tabular}} & \multicolumn{2}{|c|}{\begin{tabular}{|c|}
$\begin{array}{c}\text { K uptake } \\
\left(\mathrm{kg} \mathrm{ha}^{-1}\right)\end{array}$ \\
\end{tabular}} \\
\hline & & \multicolumn{6}{|c|}{ Grain|Straw Grain Straw Grain|Straw } \\
\hline $\mathrm{T}_{1}$ & Absolute control & 30.37 & 12.14 & 4.25 & 3.09 & 3.84 & 36.31 \\
\hline $\mathrm{T}_{2}$ & $\mathrm{GM}^{*}+100 \% \mathrm{RDF}$ & 65.60 & 27.96 & 12.91 & 8.06 & 11.13 & 91.99 \\
\hline $\mathrm{T}_{3}$ & $\begin{array}{c}\text { GM }^{*}+\text { Ghanajivamrut } 5 \mathrm{t} \mathrm{ha}^{-1}+\text { Azophos seed treatment }+50 \% \text { RD of NP through fertilizer } \\
+ \text { Jivamrut }\end{array}$ & 60.45 & 25.35 & 11.53 & 6.96 & 9.56 & 82.99 \\
\hline $\mathrm{T}_{4}$ & $\begin{array}{c}\mathrm{GM}^{*}+\text { Vermicompost } 5 \mathrm{t} \mathrm{ha}^{-1}+\text { Azophos seed treatment }+50 \% \text { RD of NP through fertilizer } \\
+ \text { Jivamrut }\end{array}$ & 60.35 & 25.77 & 11.49 & 7.32 & 9.96 & 80.26 \\
\hline $\mathrm{T}_{5}$ & $\begin{array}{c}\mathrm{GM}^{*}+50 \% \mathrm{RD} \text { of NP through fertilizer + Foliar spray of } 0.5 \% \text { of } 1000 \mathrm{ppm} \text { nano } \mathrm{P} \\
\text { suspension at tillering and flowering stage of wheat }\end{array}$ & 68.09 & 27.81 & 15.35 & 9.01 & 10.99 & 96.21 \\
\hline $\mathrm{T}_{6}$ & $\begin{array}{c}\mathrm{T}_{3}+\text { Foliar spray of } 0.5 \% \text { of } 1000 \mathrm{ppm} \text { nano P suspension at tillering and flowering stage of } \\
\text { wheat }\end{array}$ & 68.68 & 30.41 & 14.87 & 8.62 & 11.57 & 98.42 \\
\hline $\mathrm{T}_{7}$ & $\begin{array}{c}\mathrm{T}_{4}+\text { Foliar spray of } 0.5 \% \text { of } 1000 \mathrm{ppm} \text { nano } \mathrm{P} \text { suspension at tillering and flowering stage of } \\
\text { wheat }\end{array}$ & 63.12 & 28.32 & 12.64 & 7.88 & 10.83 & 89.29 \\
\hline $\mathrm{T}_{8}$ & $\mathrm{GM}^{*}+$ Ghanajivamrut $5 \mathrm{t} \mathrm{ha}^{-1}$ & 35.96 & 15.22 & 6.59 & 3.52 & 5.44 & 47.17 \\
\hline $\mathrm{T}_{9}$ & $\mathrm{GM}^{*}+$ Vermicompost $5 \mathrm{t} \mathrm{ha}^{-1}+$ Azophos seed treatment + Jivamrut & 36.78 & 15.22 & 6.55 & 3.61 & 5.57 & 47.16 \\
\hline & $\mathrm{SEm} \pm$ & 4.44 & 1.92 & 0.49 & 0.32 & 0.52 & 3.40 \\
\hline & CD at $5 \%$ & 13.30 & 5.75 & 1.48 & 0.96 & 1.54 & 10.19 \\
\hline
\end{tabular}

Nitrogen and potassium uptake in grain and straw recorded highest in the treatment $\mathrm{T}_{6}$ which is comprised of $\mathrm{T}_{3}+$ Foliar spray of $0.5 \%$ of $1000 \mathrm{ppm}$ nano $\mathrm{P}$ suspension at tillering and flowering stage of wheat i.e. $68.68 \mathrm{~kg} \mathrm{ha}^{-1}, 28.32 \mathrm{~kg} \mathrm{ha}^{-1}$ and $11.57 \mathrm{~kg} \mathrm{ha}^{-1}, 98.42 \mathrm{~kg} \mathrm{ha}^{-1}$ respectively as shown in table 2 . Nitrogen and potassium uptake recoded high in $\mathrm{T}_{6}$ might be due to application of ghanjivamrut $(0.91 \% \mathrm{~N}, 0.49 \% \mathrm{P}$ and $1.16 \% \mathrm{~K})$ and green manuring of sunhemp $(2.11 \% \mathrm{~N}, 0.31 \%$ $\mathrm{P}$ and $1.47 \% \mathrm{~K})$. Phosphorus uptake recorded highest in treatment $\mathrm{T}_{5}\left(\mathrm{GM}^{*}+50 \% \mathrm{RD}\right.$ of NP through fertilizer + Foliar spray of $0.5 \%$ of $1000 \mathrm{ppm}$ nano $\mathrm{P}$ suspension at tillering and flowering stage of wheat) i.e. $15.35 \mathrm{~kg} \mathrm{ha}^{-1}$ and $9.01 \mathrm{~kg} \mathrm{ha}^{-1}$ in grain and straw of wheat respectively. Phosphorus uptake in grain and straw is influenced due to nano $\mathrm{P}$ fertilizer spraying at tillering and flowering stages of wheat. This results were compatible with studies done by Dhansil et al. (2017) ${ }^{[3]}$. 
Nutrient use efficiency influenced by INM with nano phosphatic fertilizer

Table 3: Influence of INM with nano P fertilizer on nutrient use efficiency (\%)

\begin{tabular}{|c|c|c|c|c|}
\hline $\begin{array}{c}\text { Treat. } \\
\text { No. }\end{array}$ & Treatment Details & $\begin{array}{l}\text { Nitrogen Use } \\
\text { Efficiency }(\%)\end{array}$ & $\begin{array}{l}\text { Phosphorus Use } \\
\text { Efficiency }(\%)\end{array}$ & $\begin{array}{l}\text { Potassium Use } \\
\text { Efficiency }(\%)\end{array}$ \\
\hline $\mathrm{T}_{1}$ & Absolute control & - & - & - \\
\hline $\mathrm{T}_{2}$ & $\mathrm{GM}^{*}+100 \% \mathrm{RDF}$ & 27.61 & 21.79 & 57.51 \\
\hline $\mathrm{T}_{3}$ & $\begin{array}{c}\mathrm{GM}^{*}+\text { Ghanajivamrut } 5 \mathrm{t} \mathrm{ha}^{-1}+\text { Azophos seed treatment }+50 \% \text { RD of } \\
\text { NP through fertilizer + Jivamrut }\end{array}$ & 20.31 & 13.43 & 31.27 \\
\hline $\mathrm{T}_{4}$ & $\begin{array}{c}\mathrm{GM}^{*}+\text { Vermicompost } 5 \mathrm{t} \mathrm{ha}^{-1}+\text { Azophos seed treatment }+50 \% \text { RD of } \\
\text { NP through fertilizer + Jivamrut }\end{array}$ & 18.78 & 13.74 & 27.88 \\
\hline $\mathrm{T}_{5}$ & $\begin{array}{c}\mathrm{GM}^{*}+50 \% \text { RD of NP through fertilizer + Foliar spray of } 0.5 \% \text { of } 1000 \\
\text { ppm nano P suspension at tillering and flowering stage of wheat }\end{array}$ & 36.76 & 35.82 & 61.24 \\
\hline $\mathrm{T}_{6}$ & $\begin{array}{c}\mathrm{T}_{3}+\text { Foliar spray of } 0.5 \% \text { of } 1000 \mathrm{ppm} \text { nano P suspension at tillering } \\
\text { and flowering stage of wheat }\end{array}$ & 26.50 & 17.38 & 41.98 \\
\hline $\mathrm{T}_{7}$ & $\begin{array}{c}\mathrm{T}_{4}+\text { Foliar spray of } 0.5 \% \text { of } 1000 \mathrm{ppm} \text { nano } \mathrm{P} \text { suspension at tillering } \\
\text { and flowering stage of wheat }\end{array}$ & 21.07 & 14.10 & 33.25 \\
\hline $\mathrm{T}_{8}$ & $\mathrm{GM}^{*}+$ Ghanajivamrut $5 \mathrm{t} \mathrm{ha}^{-1}$ & 6.60 & 7.52 & 7.44 \\
\hline $\mathrm{T}_{9}$ & $\mathrm{GM}^{*}+$ Vermicompost $5 \mathrm{t} \mathrm{ha}^{-1}+$ Azophos seed treatment + Jivamrut & 5.45 & 4.57 & 6.99 \\
\hline \multicolumn{2}{|r|}{ SEm \pm} & 2.87 & 0.92 & 2.34 \\
\hline \multicolumn{2}{|r|}{ CD at $5 \%$} & 8.61 & 2.75 & 7.03 \\
\hline
\end{tabular}

\section{N, P AND K USE EFFICIENCY (\%)}

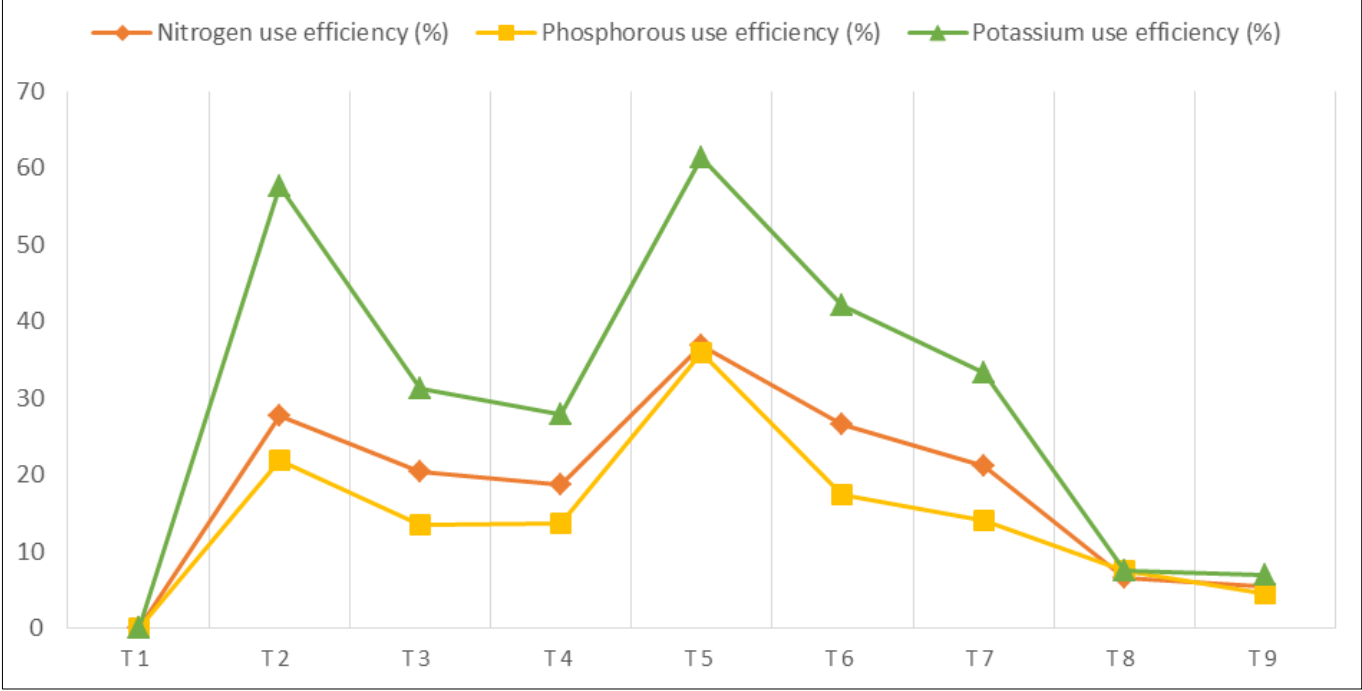

Fig 1: NPK use efficiency

As shown in table 3. and fig. 1., Nitrogen use efficiency recorded highest in treatment $\mathrm{T}_{5}\left(\mathrm{GM}^{*}+50 \% \mathrm{RD}\right.$ of $\mathrm{NP}$ through fertilizer + Foliar spray of $0.5 \%$ of $1000 \mathrm{ppm}$ nano $\mathrm{P}$ suspension at tillering and flowering stage of wheat) i.e. $36.76 \%$ which is statistically superior over other treatments. Tarafdar et al. (2015) ${ }^{[11]}$ compared P use efficiency of SSP, Soluble $\mathrm{P}\left(\mathrm{KH}_{2} \mathrm{PO}_{4}\right)$ and nano phosphorus and reported highest value of $57.8 \%$ of $\mathrm{P}$ use efficiency in case of nano $\mathrm{P}$. Phosphorus use efficiency recorded highest in treatment $\mathrm{T}_{5}$ $\left(\mathrm{GM}^{*}+50 \% \mathrm{RD}\right.$ of NP through fertilizer + Foliar spray of $0.5 \%$ of $1000 \mathrm{ppm}$ nano $\mathrm{P}$ suspension at tillering and flowering stage of wheat) i.e. $35.82 \%$ which is statistically superior over all other treatments. The maximum NPK content and uptake as well as protein content and uptake were observed with the application of 2.5-time reduction of RDF through nano phosphatic fertilizer ${ }^{[3]}$. Potassium use efficiency recorded highest in treatment $\mathrm{T}_{5}(\mathrm{GM} *+50 \% \mathrm{RD}$ of NP through fertilizer + Foliar spray of $0.5 \%$ of $1000 \mathrm{ppm}$ nano $\mathrm{P}$ suspension at tillering and flowering stage of wheat) i.e. $61.24 \%$ which is statistically at par with $\mathrm{T}_{2}\left(\mathrm{GM}^{*}+100 \%\right.$ RDF) treatment which has $57.51 \%$ Potassium use efficiency. Although, potassium as a basal dose was not applied higher use efficiency might be due to balance use of nutrients by crop.

Effect of INM and nano phosphatic fertilizer on fertility status of soil after harvest of crop

The data pertaining to effect of INM and nano phosphatic fertilizer on fertility status of soil after harvest of the crop is given table 4 .

The result revealed that the effect of different treatments found statistically non-significant on soil $\mathrm{pH}$ and EC after harvest of crop. Soil pH was recorded in between 7.60 to 7.74 and EC ranges between $0.27-0.33 \mathrm{dS} \mathrm{m}^{-1}$. The experiment resulted that the effect of INM with nano phosphatic fertilizer comprises of different treatments showed that higher organic carbon found in $\mathrm{T}_{7}$ treatment $\left(4.21 \mathrm{~g} \mathrm{~kg}^{-1}\right)$. 
Table 4: Effect of INM and nano phosphatic fertilizer on fertility status of soil after harvest of the crop

\begin{tabular}{|c|c|c|c|c|c|c|c|c|}
\hline $\begin{array}{l}\text { Treat. } \\
\text { No. }\end{array}$ & Treatment Details & $\mathbf{p H}$ & $\begin{array}{l}\text { EC } \\
(d S \\
\left.m^{-1}\right) \\
\end{array}$ & $\underset{(\mathrm{g} / \mathrm{kg})}{\mathrm{OC}}$ & $\begin{array}{c}\text { Avail. } \\
\mathbf{N} \\
(\mathbf{k g} / \mathbf{h a})\end{array}$ & $\begin{array}{c}\text { Avail. } \\
\mathrm{P}_{2} \mathrm{O}_{5} \\
\text { (kg/ha) }\end{array}$ & $\begin{array}{c}\text { Avail.K } K_{2} \mathrm{O} \\
\text { (kg/ha) }\end{array}$ & $\begin{array}{l}\text { Avail. S } \\
(\mathrm{mg} / \mathrm{kg})\end{array}$ \\
\hline $\mathrm{T}_{1}$ & Absolute control & 7.68 & 0.30 & 3.97 & 192.80 & 13.95 & 425.03 & 8.11 \\
\hline $\mathrm{T}_{2}$ & $\mathrm{GM}^{*}+100 \% \mathrm{RDF}$ & 7.71 & 0.32 & 4.08 & 239.60 & 16.27 & 475.67 & 9.41 \\
\hline $\mathrm{T}_{3}$ & $\begin{array}{c}\mathrm{GM}^{*}+\text { Ghanajivamrut } 5 \mathrm{t} \mathrm{ha}^{-1}+\text { Azophos seed treatment }+50 \% \mathrm{RD} \text { of NP } \\
\text { through fertilizer + Jivamrut }\end{array}$ & 7.63 & 0.31 & 4.15 & 230.40 & 14.28 & 474.00 & 8.63 \\
\hline $\mathrm{T}_{4}$ & $\begin{array}{c}\mathrm{GM}^{*}+\text { Vermicompost } 5 \mathrm{t} \mathrm{ha}^{-1}+\text { Azophos seed treatment }+50 \% \mathrm{RD} \text { of NP } \\
\text { through fertilizer }+ \text { Jivamrut }\end{array}$ & 7.60 & 0.31 & 4.19 & 233.13 & 14.64 & 482.00 & 8.73 \\
\hline $\mathrm{T}_{5}$ & $\begin{array}{c}\mathrm{GM}^{*}+50 \% \text { RD of NP through fertilizer + Foliar spray of } 0.5 \% \text { of } 1000 \mathrm{ppm} \\
\text { nano P suspension at tillering and flowering stage of wheat }\end{array}$ & 7.74 & 0.32 & 4.08 & 221.87 & 14.99 & 472.60 & 8.93 \\
\hline $\mathrm{T}_{6}$ & $\begin{array}{c}\mathrm{T}_{3}+\text { Foliar spray of } 0.5 \% \text { of } 1000 \mathrm{ppm} \text { nano } \mathrm{P} \text { suspension at tillering and } \\
\text { flowering stage of wheat }\end{array}$ & 7.61 & 0.31 & 4.17 & 212.70 & 15.32 & 480.30 & 9.12 \\
\hline $\mathrm{T}_{7}$ & $\begin{array}{c}\mathrm{T}_{4}+\text { Foliar spray of } 0.5 \% \text { of } 1000 \text { ppm nano P suspension at tillering and } \\
\text { flowering stage of wheat }\end{array}$ & 7.62 & 0.33 & 4.21 & 216.70 & 15.27 & 482.35 & 9.15 \\
\hline $\mathrm{T}_{8}$ & $\mathrm{GM}^{*}+$ Ghanajivamrut $5 \mathrm{t} \mathrm{ha}^{-1}$ & 7.65 & 0.30 & 4.12 & 216.40 & 14.11 & 456.00 & 8.63 \\
\hline $\mathrm{T}_{9}$ & GM $^{*}+$ Vermicompost $5 \mathrm{t} \mathrm{ha}^{-1}+$ Azophos seed treatment + Jivamrut & 7.65 & 0.30 & 4.16 & 214.73 & 14.03 & 462.00 & 8.54 \\
\hline \multirow{2}{*}{\multicolumn{2}{|c|}{$\begin{array}{c}\text { SEm } \pm \\
\text { CD at } 5 \%\end{array}$}} & 0.05 & 0.01 & 0.04 & 14.05 & 0.05 & 8.63 & 0.23 \\
\hline & & NS & NS & 0.13 & NS & 0.14 & 25.88 & 0.70 \\
\hline
\end{tabular}

Data pertaining to fertility status of soil after harvest of crop is presented in table 4 and fig. 2, available nitrogen of soil was observed between 192.80 to $239.60 \mathrm{~kg} \mathrm{ha}^{-1}$ with the different treatments consist of INM with nano phosphatic fertilizer but it was found statistically non-significant. The maximum available nitrogen in soil was observed $239.60 \mathrm{~kg}$ $\mathrm{ha}^{-1}$ with the application of 100\% RDF (100:50:50 kg NPK $\left.\mathrm{ha}^{-1}\right)$. Available phosphorus of soil was observed between 13.95 to $16.27 \mathrm{~kg} \mathrm{ha}^{-1}$. The maximum available Phosphorus was observed $16.27 \mathrm{~kg} \mathrm{ha}^{-1}$ with the application of $\mathrm{GM}^{*}+$ $100 \%$ RDF which remained significant over all other treatments. Available potassium of soil was found significant under different INM practices. The maximum available potassium in soil was observed $510.98 \mathrm{~kg} \mathrm{ha}^{-1}$ with the treatment of $\mathrm{T}_{4}+$ Foliar spray of $0.5 \%$ of $1000 \mathrm{ppm}$ nano $\mathrm{P}$ suspension at tillering and flowering stage of wheat which is at par with $\mathrm{T}_{2}, \mathrm{~T}_{3}, \mathrm{~T}_{4}, \mathrm{~T}_{5}, \mathrm{~T}_{6}$ and $\mathrm{T}_{9}$ treatment. The value of available potassium comes under high in range. In the present study, available sulphur of soil was observed between 8.11 to $9.41 \mathrm{mg} \mathrm{kg}^{-1}$ with the different treatments consist of INM with nano $\mathrm{P}$ fertilizer. The maximum available sulphur in soil was observed $9.41 \mathrm{mg} \mathrm{kg}^{-1}$ with the application of $100 \% \mathrm{RDF}$ (100: 50: $50 \mathrm{~kg} \mathrm{NPK} \mathrm{ha}^{-1}$ ) which is at par with $\mathrm{T}_{4}, \mathrm{~T}_{5}, \mathrm{~T}_{6}$ and $\mathrm{T}_{7}$ treatments.

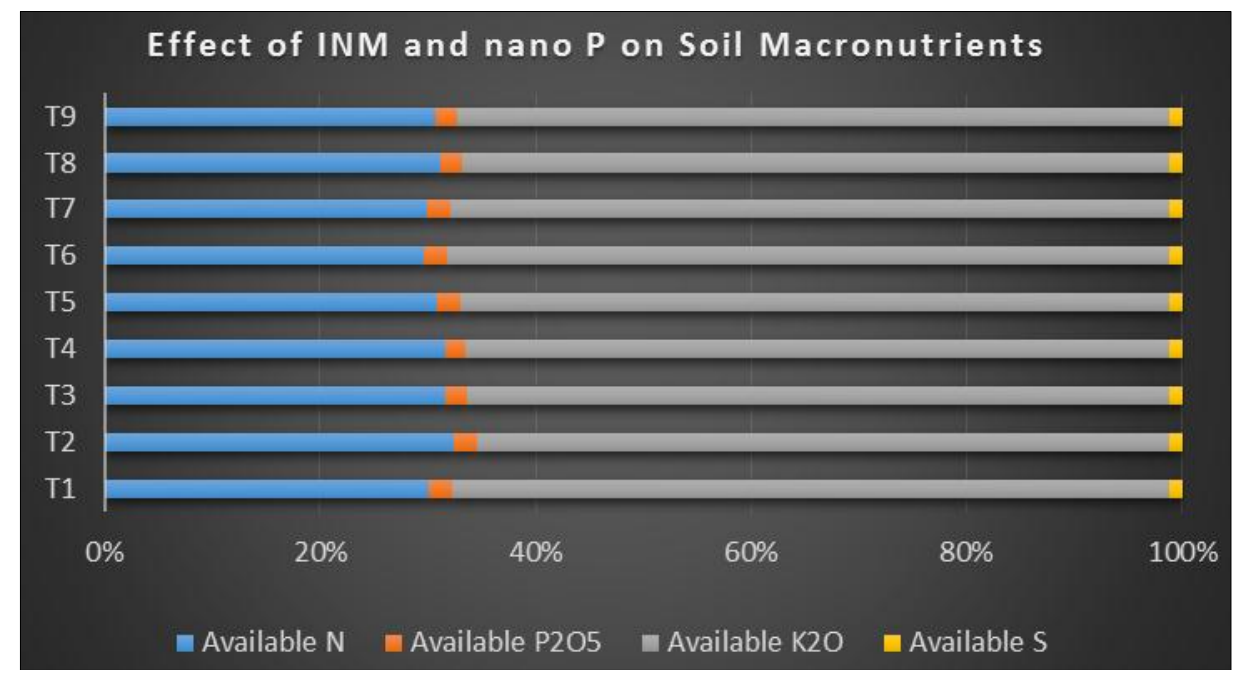

Fig 2: Effect of INM and nano P on fertility status of soil

\section{Influence of INM and nano phosphatic fertilizer on soil micronutrients after harvest of wheat}

The result related to DTPA extractable micronutrients status in soil after harvest of wheat is given in table 5 .

In the present study, DTPA extractable iron of soil was observed in between 5.23 to $6.12 \mathrm{mg} \mathrm{kg}^{-1}$ with the different treatments consist of INM with nano $\mathrm{P}$ fertilizer but it was found statistically non-significant. The maximum DTPA extractable iron in soil was observed $6.12 \mathrm{mg} \mathrm{kg}^{-1}$ with the treatment $\mathrm{T}_{7}\left(\mathrm{~T}_{4}+\right.$ Foliar spray of $0.5 \%$ of $1000 \mathrm{ppm}$ nano $\mathrm{P}$ suspension at tillering and flowering stage of wheat). DTPA extractable Mn of soil was observed between 2.52 to $2.87 \mathrm{mg}$ $\mathrm{kg}^{-1}$ with the different treatments consist of INM with nano P fertilizer. The maximum DTPA extractable manganese in soil was observed $2.87 \mathrm{mg} \mathrm{kg}^{-1}$ with the treatment $\mathrm{T}_{2}\left(\mathrm{GM}^{*}+\right.$ $100 \% \mathrm{RDF}$ ) which found significant over all other treatment. The maximum DTPA extractable zinc in soil was observed $0.77 \mathrm{mg} \mathrm{kg}^{-1}$ with the treatment $\mathrm{T}_{7}\left(\mathrm{~T}_{4}+\right.$ Foliar spray of $0.5 \%$ of $1000 \mathrm{ppm}$ nano $\mathrm{P}$ suspension at tillering and flowering stage of wheat) which found at par with treatment $T_{3}, T_{4}$ and $\mathrm{T}_{6}$. DTPA extractable $\mathrm{Cu}$ of soil was observed between 1.27 to $1.72 \mathrm{mg} \mathrm{kg}^{-1}$ with the different treatments consist of INM with nano $\mathrm{P}$ fertilizer. The maximum DTPA extractable copper in soil was observed $1.72 \mathrm{mg} \mathrm{kg}^{-1}$ with the treatment $\mathrm{T}_{2}\left(\mathrm{GM}^{*}+100 \% \mathrm{RDF}\right)$ which found at par with treatment $\mathrm{T}_{7}$ $\left(1.66 \mathrm{mg} \mathrm{kg}^{-1}\right)$. 
Table 5: DTPA extractable micronutrients status in soil after harvest of wheat

\begin{tabular}{|c|c|c|c|c|c|}
\hline $\begin{array}{c}\text { Treat. } \\
\text { No. }\end{array}$ & Treatment Details & $\begin{array}{c}\mathbf{F e} \\
(\mathrm{mg} / \mathrm{kg})\end{array}$ & $\begin{array}{c}\text { Mn } \\
(\mathbf{m g} / \mathbf{k g})\end{array}$ & $\begin{array}{c}\mathbf{Z n} \\
(\mathbf{m g} / \mathbf{k g})\end{array}$ & $\begin{array}{c}\mathrm{Cu} \\
(\mathrm{mg} / \mathrm{kg})\end{array}$ \\
\hline $\mathrm{T}_{1}$ & Absolute control & 5.83 & 2.52 & 0.60 & 1.27 \\
\hline $\mathrm{T}_{2}$ & \begin{tabular}{|c|}
$\mathrm{GM}^{*}+100 \% \mathrm{RDF}$ \\
\end{tabular} & 5.23 & 2.87 & 0.67 & 1.72 \\
\hline $\mathrm{T}_{3}$ & $\mathrm{GM}^{*}+$ Ghanajivamrut $5 \mathrm{t} \mathrm{ha}^{-1}+$ Azophos seed treatment $+50 \%$ RD of NP through fertilizer + Jivamrut & 5.92 & 2.62 & 0.71 & 1.37 \\
\hline $\mathrm{T}_{4}$ & $\mathrm{GM}^{*}+$ Vermicompost $5 \mathrm{t} \mathrm{ha}^{-1}+$ Azophos seed treatment $+50 \%$ RD of NP through fertilizer + Jivamrut & 5.91 & 2.64 & 0.73 & 1.44 \\
\hline $\mathrm{T}_{5}$ & $\begin{array}{c}\mathrm{GM}^{*}+50 \% \text { RD of NP through fertilizer }+ \text { Foliar spray of } 0.5 \% \text { of } 1000 \mathrm{ppm} \text { nano P suspension at } \\
\text { tillering and flowering stage of wheat }\end{array}$ & 6.06 & 2.80 & 0.69 & 1.56 \\
\hline $\mathrm{T}_{6}$ & $\mathrm{~T}_{3}+$ Foliar spray of $0.5 \%$ of $1000 \mathrm{ppm}$ nano $\mathrm{P}$ suspension at tillering and flowering stage of wheat & 6.10 & 2.76 & 0.72 & 1.64 \\
\hline $\mathrm{T}_{7}$ & $\mathrm{~T}_{4}+$ Foliar spray of $0.5 \%$ of $1000 \mathrm{ppm}$ nano $\mathrm{P}$ suspension at tillering and flowering stage of wheat & 6.12 & 2.78 & 0.77 & 1.66 \\
\hline $\mathrm{T}_{8}$ & GM* + Ghanajivamrut $5 \mathrm{t} \mathrm{ha}^{-1}$ & 5.82 & 2.59 & 0.69 & 1.41 \\
\hline $\mathrm{T}_{9}$ & $\mathrm{GM}^{*}+$ Vermicompost $5 \mathrm{t} \mathrm{ha}^{-1}+$ Azophos seed treatment + Jivamrut & 5.87 & 2.64 & 0.70 & 1.45 \\
\hline \multicolumn{2}{|r|}{$\mathrm{SEm} \pm$} & 0.37 & 0.02 & 0.02 & 0.02 \\
\hline \multicolumn{2}{|r|}{$\mathrm{CD}$ at $5 \%$} & NS & 0.05 & 0.06 & 0.07 \\
\hline
\end{tabular}

\section{Conclusion}

The study revealed that maximum yield of wheat, $\mathrm{P}$ uptake and NPK use efficiency recorded under GM* $+50 \%$ RD of NP through fertilizer + Foliar spray of $0.5 \%$ of $1000 \mathrm{ppm}$ nano $\mathrm{P}$ suspension at tillering and flowering stage of wheat treatment. $\mathrm{N}$ and $\mathrm{K}$ uptake recorded highest. Available $\mathrm{N}$ and $\mathrm{P}(\mathrm{kg} / \mathrm{ha})$, available $\mathrm{S}\left(\mathrm{mg} \mathrm{kg}^{-1}\right)$ and DTPA extractable $\mathrm{Mn}$ and $\mathrm{Zn}(\mathrm{mg} / \mathrm{kg})$ recorded higher in treatment comprises of $\mathrm{GM}^{*}+100 \%$ RDF. INM with nano $\mathrm{P}$ fertilizer found comparable with Phosphorus application through conventional sources which indicated that chemical load and fertilizer cost may be reduced without affecting the yield of wheat.

\section{Acknowledgement}

The author gratefully acknowledge the department of Soil Science and Agricultural Chemistry, College of Agriculture, Nagpur under Dr. Panjabrao Deshmukh Krishi Vidyapeeth, Akola (MH), India for the support to research work. We also thank for the help rendered by Associate Director of Research (Agri.), A.A.U., Anand, Assistant Research Scientist and Head, Department of Nanotechnology and Centre for Advanced Research in Plant Tissue Culture, A. A. U., Anand and all staff members of his office.

\section{References}

1. Anonymous. Agricultural stat at glance 2018. Government of India, 2019.

2. Chesnin L, Yien CH. Turbidimetric determination of available Sulphates. Soil Sci. Soc. America proceedings. $1951 ; 15: 149-151$.

3. Dhansil A, Zalawadia NM, Prajapati BS, Yadav K. Effect of nano phosphatic fertilizer on nutrient content and uptake by Pearl millet (Pennisetum glaucum L.) crop. Int. J. Curr. Micrbiol. App. Sci. 2018; 7(12):2327-2337.

4. Jackson ML. Soil Chemical Analysis prentice hall of India. Private Limited New Delhi, 1973, 151-153.

5. Javaria S, Khan MQ. Impact of integrated nutrient management on tomato yield, quality and soil environment. J. Plant Nutri. 2010; 34(1):140-149.

6. Lindsay WL, Norvell WA. Development of DTPA soil test for Fe, Mn, Zn and Cu. Soil Sci. Soc. of American J. 1978; 42:421-427.

7. Mateus AYP, Ferraz MP, Monterio FJ. Comparative study of nanohydroxyapatite microspheres for medical applications. Inc. J. Biomed. Mater. Res. 2007; 86A:483493.
8. Mortvedt JJ. Crop response to level of water soluble zinc in granular zinc fertilizer. Fertilizer research. 1992; 33(3):249-255.

9. Pattnyak SK, Sureshkumar P, Tarafdar JC. New vista in Phosphorus research. J. Indian. Soc. Soil Sci. 2009; 57(4):536-545.

10. Singh MD, Gautam Chirag, Patidar Om Prakash, Prakasha G, Vishwajith. Nanoferilizer is a New Way to Increase Nutrient Use Efficiency in Crop Production. Int. J. of Agril. Sci. 2017; 9(7):3831-3833.

11. Tarafdar JC, Rathor I, Thomas E. Enhancing nutrient use efficiency through nano technological interventions. Indian J. Fert. 2015; 11(12):46-51.

12. Trenkel ME. Controlled-release and stabilized fertilizers in agriculture. Int. Ferti. Industry Asso. 1997; 11:1-157.

13. Rameshaiah GN, Pallavi J, Shabnam S. Nano fertilizers and nano sensors - an attempt for developing smart agriculture. Int. J. Engi. Res. Gen. Sci. 2015; 3(1):314320 .

14. Subbaiah BV, Assija GL. A rapid procedure for the estimation of available nitrogen in soils. Current Sci. 1956; 25:259-260.

15. Walkley NM, Black AI. Estimation of organic carbon by chromic acid titration method Soil Science. 1934; 25:259-263.

16. Zak AK, Razali R, Majid W, Darroundi M. Synthesis and characterization of a narrow size distribution of $\mathrm{ZnO}$ nanoparticles. Int. J. of Nanomedicine. 2011; 6:1399-140. 